\section{Commentary: Hands off the pulmonary veins!}

\author{
Federica Caldaroni, $\mathrm{MD},{ }^{\mathrm{a}}$ and \\ Yves d'Udekem, MD, $\mathrm{PhD}^{\mathrm{a}, \mathrm{b}, \mathrm{c}}$
}

Despite the intimidating name and aura encasing the total anomalous pulmonary venous return, the last decades advances in surgical and perfusion approaches and postoperative management have resulted in dramatic improvement in the overall survival of these patients. ${ }^{1}$ Postoperative pulmonary venous obstruction (PVO), however, despite being less frequent, with rates ranging from $10 \%$ to $25 \%$ of cases, ${ }^{2,3}$ is still a challenging complication, significantly affecting long-term survival.

In this issue of the Journal, Masaki and colleagues ${ }^{5}$ report an innovative and interesting study, developing a pig animal model of pulmonary vein obstruction after total anomalous pulmonary venous return repair, which they have tested with rapamycin-eluting films, to prevent the development of postsurgical stenosis. Despite a few criticisms about their claim that this swine model closely mimics human pulmonary venous obstruction, when clearly there are histopathologic and surgical differences in this comparison, this is a remarkable work and provides new grasp into the poorly understood etiopathogenesis of the PVO.

Masaki and colleagues ${ }^{5}$ analyzed the histologic changes that occurred in the pulmonary veins of the animal models, paying attention to the expression patterns of the smooth muscle-like cells, deemed responsible for the reendothelialization process observed after surgery for total anomalous pulmonary venous return repair. Their belief is that hyperplasia-inhibitor agents, such as rapamycin, could be used to prevent the development of upstream PVO, thus

\footnotetext{
From the ${ }^{a}$ Department of Cardiac Surgery, Royal Children's Hospital; ${ }^{b}$ Heart Research, Murdoch Children's Research Institute; and ' Department of Paediatrics, The University of Melbourne, Melbourne, Victoria, Australia.

Disclosures: Dr d'Udekem is a consultant for MSD and Actelion. He also is a NHMRC Clinician Practitioner Fellow [1082186]. Dr Caldaroni has nothing to disclose with regard to commercial support.

Received for publication Feb 10, 2020; revisions received Feb 10, 2020; accepted for publication Feb 11, 2020; available ahead of print Feb 19, 2020.

Address for reprints: Yves d'Udekem, MD, PhD, FRACS, Department of Cardiac Surgery, The Royal Children's Hospital Melbourne, 50 Flemington Rd, Parkville 3052, Victoria, Australia (E-mail: yves.dudekem@rch.org.au).

J Thorac Cardiovasc Surg 2020;160:791

$0022-5223 / \$ 36.00$

Copyright (c) 2020 by The American Association for Thoracic Surgery

https://doi.org/10.1016/j.jtcvs.2020.02.044
}

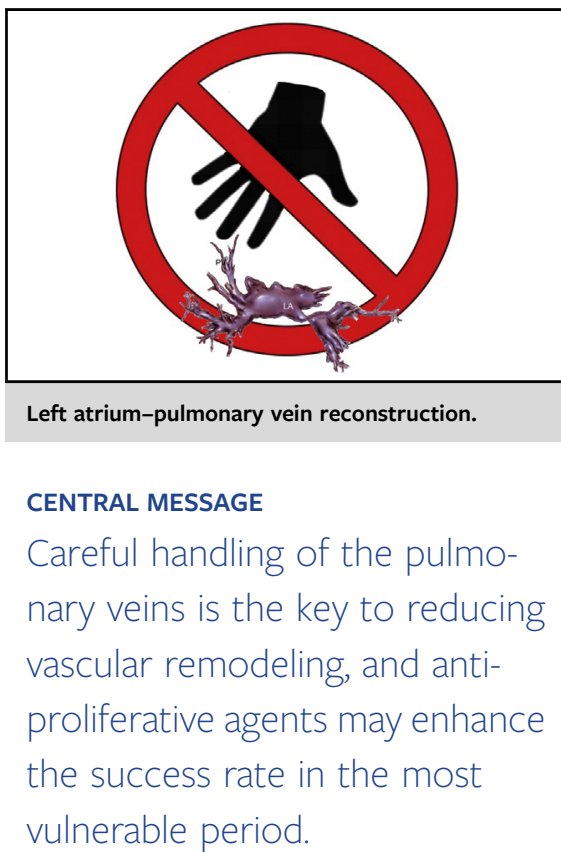

improving the outcomes and reducing the reoperation rates in human patients.

The aim of the study is remarkable and high-minded; however, at the current state of the art, the results are still far off to be attainable. The study in fact demonstrates that the pulmonary veins treated with rapamycin films show a reduced expression of the smooth muscle-like cells and a lower rate of stenosis at the anastomotic site. The clinical advantage disappears after 8 weeks, however, with evidence of pulmonary vein occlusion in all the swine models.

Among the attempts to prevent PVO, the sutureless repair, at some stage, seemed to be the holy grail for this problem. Recent studies, however, have shown that the results are not much different in terms of survival or reoperation rate, ${ }^{2,4}$ coming full circle to the original conundrum.

What is demonstrated so far is that tissue injury resulting from poor surgical handling and lack of growth resulting from constriction at the anastomotic site are the major factors implicated in the pathogenesis of PVO. In this regard, the use of endovascular stents is not advisable, because it promotes neo-endothelialization, ${ }^{3}$ nor are antihyperplasia agents adequate to stop the adverse progression, providing only transitory advantage.

The process of vascular remodeling in pulmonary veins is a field still to be explored and likely the solution will not be unifocal. The study of Masaki and colleagues ${ }^{5}$ provides new insights into treatment at molecular level, but reasonably 
the main contribution will come from more careful surgical manipulation, respecting the "sensitive" pulmonary veins.

\section{References}

1. van de Wal HJ, Hamilton DI, Godman MJ, Harinck E, Lacquet LK, van Oort A. Pulmonary venous obstruction following correction for total anomalous pulmonary venous drainage: a challenge. Eur J Cardiothorac Surg. 1992;6:545-9.

2. Seale AN, Uemura H, Webber SA, Partridge J, Roughton M, Ho SY, et al; British Congenital Cardiac Association. Total anomalous pulmonary venous connection: morphology and outcome from an international population-based study. Circulation. 2010;122:2718-26.

3. White BR, Ho DY, Faerber JA, Katcoff H, Glatz AC, Mascio CE, et al. Repair of total anomalous pulmonary venous connection: risk factors for postoperative obstruction. Ann Thorac Surg. 2019;108:122-9.

4. Wu Y, Xin L, Zhou Y, Kuang H, Jin X, Li Y, et al. Is sutureless technique beneficial in the primary repair of total anomalous pulmonary venous connection? A systematic review and meta-analysis. Pediatr Cardiol. 2019;40:881-91.

5. Masaki N, Adachi O, Katahira S, Saiki Y, Horii A, Kawamoto S, et al. Progression of vascular remodeling in pulmonary vein obstruction. J Thorac Cardiovasc Surg. 2020;160:777-90.e5.
See Article page 777 .

\section{Commentary: The dam, the river, and the riverbank - Should we look at pulmonary vein obstruction from a different perspective?}

\author{
Mauro Lo Rito, MD
}

Pulmonary vein obstruction (PVO) may occur as a primary congenital disease or as a complication of total anomalous pulmonary vein return surgical repair. In both forms, when the disease acquires the malignant characteristics of upstream progression, ${ }^{1}$ there are no effective therapies able to change its lethal fate. The disease mechanism and progression have been thoroughly explored with a large animal model that reproduces the disease progression. $^{2}$

In this issue of the Journal, Masaki and colleagues ${ }^{3}$ report on their proposed new large animal model than encompasses a surgical suture of the left lower pulmonary vein. They elegantly designed a study to understand the disease mechanism, which they divided into two experiments. First, they set up the model and identified a

\footnotetext{
From the Department of Congenital Cardiac Surgery, IRCCS Policlinico San Donato, San Donato Milanese, Milan. Italy.

Disclosures: Author has nothing to disclose with regard to commercial support.

Received for publication Feb 10, 2020; revisions received Feb 10, 2020; accepted for publication Feb 11, 2020; available ahead of print Feb 19, 2020.

Address for reprints: Mauro Lo Rito, MD, Department of Congenital Cardiac Surgery, IRCCS Policlinico San Donato, San Donato Milanese, Milan, Italy (E-mail: mauro.lorito@gmail.com).

J Thorac Cardiovasc Surg 2020;160:792-3

$0022-5223 / \$ 36.00$

Copyright (c) 2020 by The American Association for Thoracic Surgery

https://doi.org/10.1016/j.jtcvs.2020.02.045
}

Check for updates

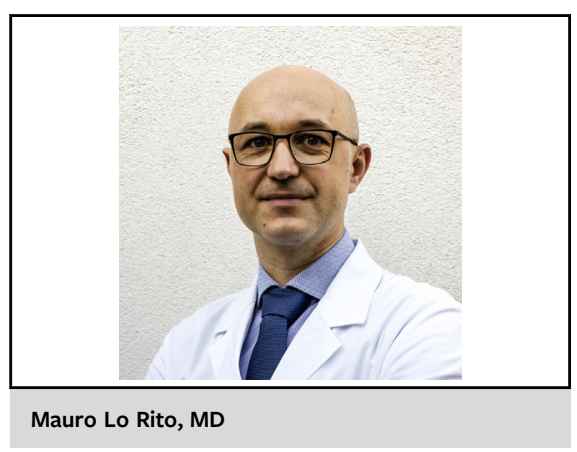

CENTRAL MESSAGE

Pulmonary vein obstruction is a lethal disease without effective therapy. We are looking for new treatments, such as the rapamycin patch, but we probably miss the overall picture to be successful.

possible treatment target. Second, they evaluated the treatment effect by inhibition of the identified target. Interestingly, they found that PVO is driven mainly by the dedifferentiation of smooth muscle-like cells and activation of mammalian target of rapamycin (mTOR) pathway. $^{3}$

Their findings seem different from the other proposed mechanisms, such as the endothelial to mesenchymal transition and transforming growth factor $\beta_{1}$ pathway activation., ${ }^{2,4}$ They are not contrary to what has been previously reported, however, and their newly described activation pathway should be interpreted as another process activated in PVO disease. Masaki and colleagues ${ }^{1}$ propose the application of a rapamycin (mTOR pathway blocker) patch at the anastomotic site to reduce the PVO 